\title{
Validity and consistency of an outpatient department user satisfaction rapid scale
}

\author{
Arturo García-Galicia, ${ }^{1}$ José Francisco Díaz-Díaz, ${ }^{2}$ Álvaro José Montiel-Jarquín, ${ }^{3 *}$ \\ Akihiki Mizuki González-López, ${ }^{4}$ Eduardo Vázquez-Cruz ${ }^{5}$ and Carlos FranciscoMorales-Flores ${ }^{1}$ \\ ${ }^{1}$ Centro Médico Nacional "General de División Manuel Ávila Camacho", Trauma and Orthopedics Hospital; ${ }^{2}$ Regional General Hospital 20; ${ }^{3}$ Centro \\ Médico Nacional "General de Div. Manuel Ávila Camacho", Specialty Hospital; ${ }^{4}$ Family Medicine Unit 1; ${ }^{5}$ Family Medicine Unit 6. Instituto Mexicano \\ del Seguro Social, Puebla, Mexico
}

\begin{abstract}
Background: User satisfaction is key to define and assess the quality of care; however, there is no patient satisfaction rapid scale in Mexico. Our objective was to determine the validity and consistency of an outpatient department user satisfaction rapid scale (ERSaPaCE). Method: Comparative, observational, cross-sectional, prolective study. In phase 1, a rapid scale model was developed, which was submitted to experts in medical care for assessment; the instrument was pilot-tested in 10-patient groups, using as many rounds as required until it obtained 20 approvals. In phase 2, the resulting questionnaire and the Outpatient Service User Satisfaction (SUCE) scale were applied to outpatient department users. ERSaPaCE was reapplied by telephone 10 days later. Descriptive statistics, Cronbach's $\alpha$, Spearmans correlation and intra-class correlation coefficient (ICC) were used. Results: Two-hundred patients were recruited, out of which $53 \%$ were aged 31-60 years; $51.5 \%$ were women and $48.5 \%$ men, all of them users of outpatient services from 13 specialties. Cronbach's $\alpha$ for ERSaPaCE was 0.608 , whereas ICC was $0.98(p=0.000)$. Convergent validity was $0.681(p=0.000)$ using Spearmans rho. Conclusion: ERSaPaCE was a valid and consistent instrument for the assessment of outpatient department user satisfaction.
\end{abstract}

KEY WORDS: Validity. Consistency. Quality of care. Patient satisfaction. SUCE. ERSaPaCE.

\section{Validez y consistencia de una escala rápida de satisfacción del paciente de consulta externa}

\section{Resumen}

Antecedentes: La satisfacción del usuario es clave para definir y valorar la calidad de la atención, sin embargo, no existe una escala rápida de satisfacción del paciente en México. El objetivo fue determinar la validez y consistencia de la Escala Rápida de Satisfacción del Paciente de Consulta Externa (ERSaPaCE). Método: Estudio comparativo, observacional, transversal, prolectivo. En la fase 1 se elaboró un modelo de escala rápida, que se sometió a la valoración de expertos en atención médica; se realizaron pruebas piloto con 10 pacientes por ronda, tantas veces como fuera necesario hasta lograr 20 aprobaciones. En la fase 2 se aplicó el cuestionario resultante y la escala de Satisfacción del Usuario de Consultas Externas (SUCE) a usuarios de consulta externa; la ERSaPaCE se reaplicó telefónicamente siete a 10 días después. Se utilizó estadística descriptiva, $\alpha$ de Cronbach, Spearman y coeficiente de correlación intraclase (CCI). Resultados: Se reclutaron 200 pacientes, $53 \%$ con edad de 31 a 60 años, $51.5 \%$ mujeres y $48.5 \%$ hombres de la consulta externa de 13 especialidades; $\alpha$ de Cronbach de ERSaPaCE $=0.608, \mathrm{CCl}=0.98(p=0.000)$ y validez convergente $=0.681(p=0.000)$ por rho de Spearman. Conclusión: ERSaPaCE fue un instrumento válido y consistente para evaluar la satisfacción del usuario de consulta externa.

PALABRAS CLAVE: Validez. Consistencia. Calidad de la atención. Satisfacción del paciente. SUCE. ERSaPaCE.

Correspondence:

*Álvaro José Montiel-Jarquín

E-mail: dralmoja @ hotmail.com
Gac Med Mex. 2020;156:45-50

Contents available at PubMed

www.gacetamedicademexico.com

0016-3813/@ 2019 Academia Nacional de Medicina de México, A.C.. Published by Permanyer. This is an open access article under the CC BY-NC-ND license (http://creativecommons.org/licenses/by-nc-nd/4.0/). 


\section{Introduction}

Quality of medical care has become an essential requirement in health services. Although scientific-technological advances have had a great impact on the improvement of the quantity and quality of life for many patients, it has also generated numerous problems with negative consequences, which affect health care in one way or another. ${ }^{1}$ On the other hand, the convergence of administrators and professionals in the field of health, the increase in the costs and use of services by the population, as well as patient demands, forces to look for standards to meet patients' expectations to the maximum. ${ }^{2}$

In Mexico there are various backgrounds, since the 1962 edition of Auditoría Médica (Medical Audit), launched by the Mexican Institute of Social Security, and its updates in 1972 and 1973, with an emphasis on the medical record. In 1981, Donabedian initiated the evaluation of the quality of medical care itself based on the systems theory. Finally, since 1999, the Ministry of Health has designed a hospital certification model to improve health care in Mexico. ${ }^{3-7}$

The quality of medical care can be defined as "granting the patient medical attention in a timely manner, with professional competence, safety and respect for ethical principles, with the purpose to meet his/her health needs and expectations",7,8

Outpatient department user satisfaction expresses an individual and subjective value judgment that is key in the definition and assessment of the quality of care, and it is therefore an indicator to assess the quality of care in health services. ${ }^{5,6}$ This construct includes treating the patient with kindness, availability of equipment, material, supplies and required medications, sufficient and qualified personnel, continuity in the process of care, comfort in the service areas and reasonable costs. ${ }^{8,9}$

Thus, outpatient department user satisfaction surveys require psychometric properties that ensure their reliability and validity and, therefore, it is necessary to have validated and readily applicable surveys available in order to measure the level of satisfaction and identify the main causes of outpatient health service users dissatisfaction, which allow implementing actions for improvement..$^{8-10}$ On the other hand, given that satisfaction is a subjective construct, it is preferable using self-report scales, which are considered the standard criterion for this type of variables. ${ }^{11,12}$

Although there are several reports on user satisfaction, ${ }^{13-15}$ in Mexico there is no rapid scale available to assess user satisfaction in secondary care facilities. For this reason, we believe it is necessary to develop an instrument that helps to subject the institution or health service to an improvement program and thus offer quality care that meets the expectations of patients and their families.

The instrument that is intended to be designed must be a rapid, functional, self-report (if possible) scale, in order for the patient not having to invest much time or effort on answering it, and at the same time prove that the instrument is valid and consistent. The purpose of this study was to design a new secondary care outpatient department user satisfaction rapid scale and determine its validity and consistency.

\section{Method}

Comparative, longitudinal, prolective, homodemic observational study in patients cared for at outpatient services of Regional General Hospital 20 of the Mexican Institute of Social Security in Puebla, upon leaving the department. The study was approved by the Local Research and Ethics on Health Research Committee 2102 of the Mexican Institute of Social Security (registration number R-2013-2102-20). Patients of both genders, regardless of their age, who agreed to answer the survey were included. Subjects who did not complete the questionnaire were eliminated.

\section{Phase 1. Development of the scale}

A fast-scale model was developed (by a committee of experts: a quality consultant psychologist, a pediatrician expert in quality and clinimetrics and an expert in outpatient services), and subsequently was submitted for assessment by different experts in the area (a master in hospital administration, the director of the unit and two hospital quality of care supervisors). The scale was subjected to a pilot study with users in order for wording clarity, ease of response and rapidness and practicality to be determined; modifications were made in these aspects without affecting the expert opinion. The pilot study was repeated as many times (10 patients per round) as necessary until total approval of 20 patients was achieved.

\section{Phase 2. Validity and consistency phase}

In a six-month period, all outpatient service users were applied the questionnaire resulting from phase 1 , the Outpatient Department User Satisfaction Rapid 


\section{Escala Rápida de Satisfacción de Consulta Externa (ERSaPaCE)}

Name (optional):

Telephone (optional):

Attended outpatient department:

APPRECIATED AFFILIATE: with the purpose to rate the quality of care, we respectfully ask you to answer the following survey. We appreciate your understanding and sincerity. Your answers will be confidential.

\begin{tabular}{|c|c|c|c|c|c|}
\hline \multirow{2}{*}{$\begin{array}{l}\text { INSTRUCTIONS: Mark with an " } x \text { " the } \\
\text { answer you choose }\end{array}$} & \multicolumn{5}{|c|}{ PARAMETERS } \\
\hline & 1 & 2 & 3 & 4 & 5 \\
\hline How do you rate... & 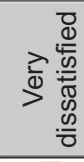 & 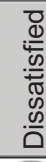 & 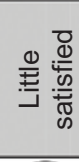 & 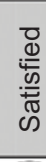 & $>\frac{\pi}{0}$ \\
\hline 1. Cleanness and order in the Medical Unit? & & & & & \\
\hline 2. Personal treatment by the Medical Assistant? & & & & & \\
\hline 3. Treatment, respect, attention and availability by the Nursir & & & & & \\
\hline $\begin{array}{l}\text { 4. Treatment, respect, attention and availability by } \\
\text { the GP or Treating Physician? }\end{array}$ & & & & & \\
\hline 5. Information by the Doctor about the patient health status? & & & & & \\
\hline $\begin{array}{l}\text { 6. Assistance at the Medical Records Department } \\
\text { window when requesting your record? }\end{array}$ & & & & & \\
\hline 7. Assistance at the Pharmacy to fill your prescription? & & & & & \\
\hline 8. Doctor, Nurse and Medical Assistant institutional image? & & & & & \\
\hline 9. Time in the waiting room for your medical appointment? & & & & & \\
\hline
\end{tabular}

10. According to your answers above, the medical unit should:

a. Be congratulated for its valuable and effective performance

b. Receive suggestions to improve the medical service

c. Receive complaints to express your dissatisfaction with the medical service

Please write down your congratulations, suggestions or complaints:

\begin{tabular}{|l|}
\hline \\
\hline
\end{tabular}

Figure 1. Outpatient department user satisfaction rapid scale.

Scale (ERSaPaCE - Escala Rápida de Satisfacción del Paciente de Consulta Externa), as well as the Outpatient Service User Satisfaction (SUCE - Satisfacción del Usuario de Consultas Externas) scale. ${ }^{10}$ In each case, ERSaPaCE was reapplied by telephone between seven and 10 days later.
Written informed consent was requested to the outpatient department users; any intervention that could involve any harm to the patient was avoided, and confidentiality of data was kept to avoid possible negative consequences with regard to medical care at the unit. 
Table 1. Characteristics of SUCE and ERSaPaCE scales respondents and their distribution in outpatient services by medical specialty

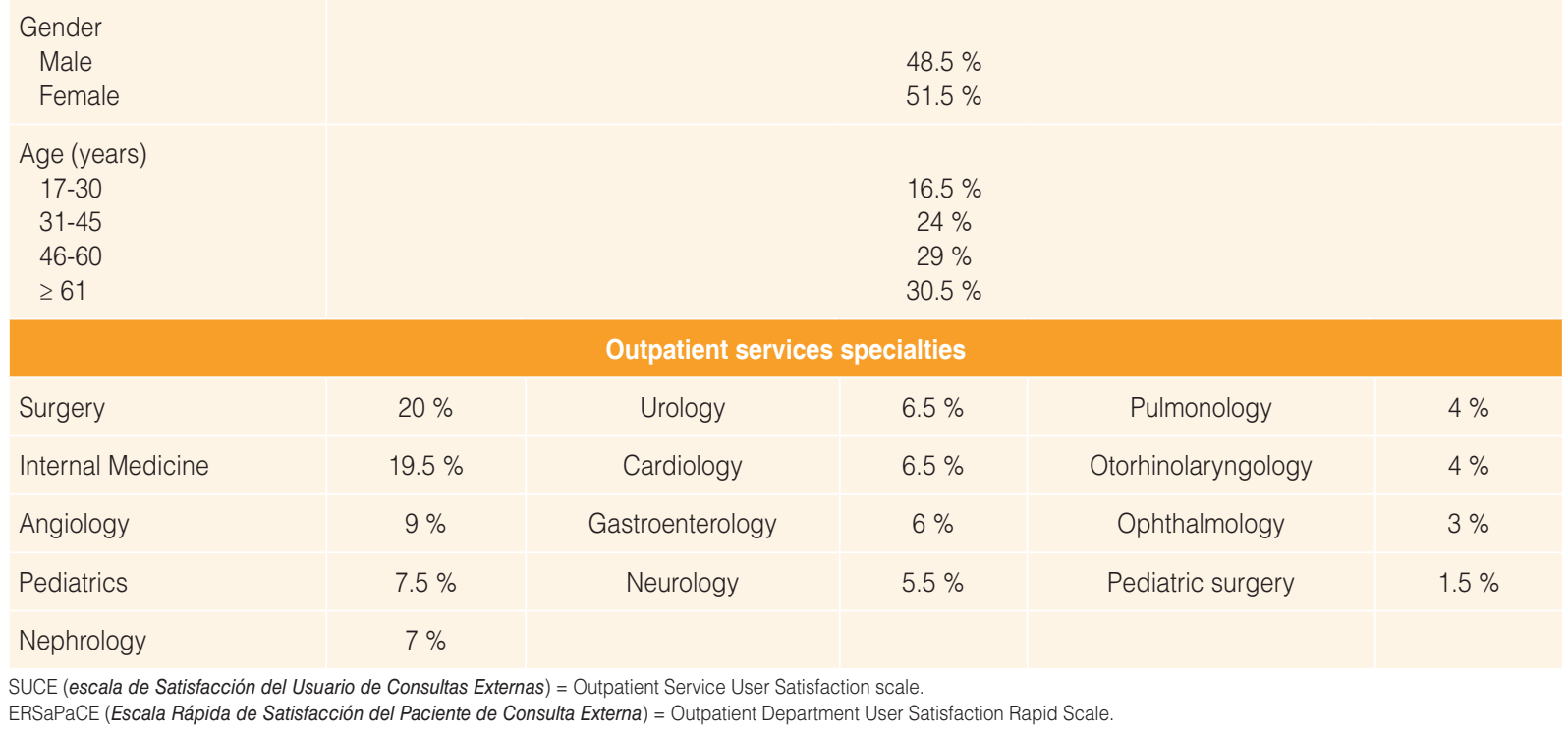

Descriptive statistics were used. For internal consistency evaluation, Cronbach's $\alpha$ was used; for convergent validity of the scales, Spearman's rho; and for test-retest of the rapid scale, the intraclass correlation coefficient (ICC) was resorted to. ${ }^{16}$

\section{Results}

\section{Phase 1}

The scale that was designed and approved by the experts required three pilot rounds until the wording of the questions was accepted by the users. To improve items applicability and reinforce their understanding, the decision was made to add, to each value of the responses, the drawings of faces used in a facial pain scale, ${ }^{11}$ whose construct validity was widely demonstrated. This phase ended with the conclusion of the scale, as shown in Figure 1.

\section{Phase 2}

Two-hundred patients who were users of the outpatient services from different specialties were surveyed; their characteristics are detailed in Table 1. There were no patients eliminated from the study. In the case of minors, SUCE and ERSaPaCE were applied to the parents or accompanying adults.

The result when Cronbach's $\alpha$ was applied to ER$\mathrm{SaPaCE}$ was 0.608 , whereas the ICC result for test-retest agreement was $0.98(p=0.000)$. The correlation of both scales using Spearman's coefficient was 0.681 $(p=0.000)$. The results for both scales are shown in Table 2.

ERSaPaCE included a section for congratulations, suggestions and complaints; textually, the most common were the following:

- Improve the service in the medical records department, please.

- More frequent cleaning in bathrooms; there are no disposable towels or paper.

- The treating physician should change his attitude.

- The doctor does not explain my condition, is arrogant and yelled at me.

- Please, supply medications to the pharmacy.

- The guards are arrogant and rude.

- Congratulations (to three different treating physicians).

\section{Discussion}

Given that patient satisfaction is useful, although indirectly, to determine the quality of care, various efforts to assess it from different angles and with varying depths are recorded. $6,8-10,13-15$

This study presents a hospital outpatient service user satisfaction scale that can be applied at any medical unit or ambulatory care area of any level of care, in addition to complying with the characteristics of brevity, rapidness, practicality for being answered; with this instrument, it is possible for different services or moments of outpatient care to be assessed.

The phase 1 procedure of the study, which involved the participation of up to 10 different experts in the 
Table 2. Comparison of SUCE and ERSaPaCE results

\begin{tabular}{|c|c|c|c|}
\hline \multicolumn{2}{|c|}{ SUCE scale } & \multicolumn{2}{|l|}{ ERSaPaCE } \\
\hline \multicolumn{2}{|c|}{$\begin{array}{l}\text { Waiting room } \\
\text { comfortability }\end{array}$} & \multicolumn{2}{|c|}{ Cleanness and order of the medical unit } \\
\hline $\begin{array}{l}1 \text { point } \\
4 \text { points } \\
5 \text { points } \\
6 \text { points } \\
7 \text { points } \\
8 \text { points } \\
9 \text { points } \\
10 \text { points }\end{array}$ & $\begin{array}{c}0.5 \% \\
1 \% \\
3.5 \% \\
2.5 \% \\
7 \% \\
16 \% \\
30 \% \\
39.5 \%\end{array}$ & $\begin{array}{l}\text { Very dissatisfied } \\
\text { Dissatisfied } \\
\text { Little satisfied } \\
\text { Satisfied } \\
\text { Very satisfied }\end{array}$ & $\begin{array}{l}2 \% \\
4 \% \\
17 \% \\
50 \% \\
27 \%\end{array}$ \\
\hline
\end{tabular}

Treatment by the nursing staff

\begin{tabular}{|l|c|l|c|}
\hline 3 points & $0.5 \%$ & Very dissatisfied & $0.5 \%$ \\
\hline 5 points & $1 \%$ & Dissatisfied & $6 \%$ \\
6 points & $2.5 \%$ & Little satisfied & $13 \%$ \\
7 points & $4 \%$ & Satisfied & $44.5 \%$ \\
\hline 8 points & $17.5 \%$ & Very satisfied & $36 \%$ \\
\hline 9 points & $27.5 \%$ & & \\
\hline 10 points & $47 \%$ & & \\
\hline
\end{tabular}

Treatment by the medical staff

\begin{tabular}{|l|c|l|c|}
\hline 1 point & $1 \%$ & Very dissatisfied & $0 \%$ \\
\hline 3 points & $2 \%$ & Dissatisfied & $7.5 \%$ \\
\hline 4 points & $0.5 \%$ & Little satisfied & $13.5 \%$ \\
\hline 5 points & $1 \%$ & Satisfied & $34 \%$ \\
\hline 6 points & $2.5 \%$ & Very satisfied & $45 \%$ \\
\hline 7 points & $6 \%$ & & \\
8 points & $12 \%$ & & \\
9 points & $29.5 \%$ & & \\
10 points & $45.5 \%$ & &
\end{tabular}

Information received Information by the doctor about your about your health problem

\begin{tabular}{l|cll}
\hline 3 points & $0.5 \%$ & Very dissatisfied & $0.5 \%$ \\
4 points & $1 \%$ & Dissatisfied & $6 \%$ \\
5 points & $4 \%$ & Little satisfied & $13 \%$ \\
6 points & $1.5 \%$ & Satisfied & $37.5 \%$ \\
7 points & $9 \%$ & Very satisfied & $43 \%$ \\
8 points & $12.5 \%$ & & \\
9 points & $31.5 \%$ & & \\
10 points & $40 \%$ & & \\
\hline & & & \\
\hline Paperwork that had & Response at the medical records \\
to be done at the & department window when requesting \\
admission office & your record & \\
\hline 1 point & $1 \%$ & Very dissatisfied & $2.5 \%$ \\
3 points & $2 \%$ & Dissatisfied & $9.5 \%$ \\
4 points & $0.5 \%$ & Little satisfied & $12.5 \%$ \\
5 points & $1.5 \%$ & Satisfied & $40 \%$ \\
6 points & $2 \%$ & Very satisfied & $35.5 \%$ \\
7 points & $7 \%$ & & \\
8 points & $23 \%$ & & \\
9 points & $31.5 \%$ & & \\
10 points & $31.5 \%$ & &
\end{tabular}

Table 2. Comparison of SUCE and ERSaPaCE results (Continued)

\begin{tabular}{|c|c|c|}
\hline \multirow[t]{2}{*}{ SUCE scale } & \multirow{2}{*}{\multicolumn{2}{|c|}{\begin{tabular}{|l} 
ERSaPaCE \\
Waiting time in minutes
\end{tabular}}} \\
\hline & & \\
\hline & $\begin{array}{l}10-15 \text { minutes } \\
16-30 \text { minutes } \\
31-60 \text { minutes } \\
61-120 \text { minutes } \\
121-180 \text { minutes } \\
\text { More than } \\
180 \text { minutes }\end{array}$ & $\begin{array}{c}21 \% \\
25.5 \% \\
35 \% \\
16 \% \\
2 \% \\
0.5 \%\end{array}$ \\
\hline
\end{tabular}

SUCE (escala de Satisfacción del Usuario de Consultas Externas) = Outpatient Service User Satisfaction scale.

ERSaPaCE (Escala Rápida de Satisfacción del Paciente de Consulta Externa) = Outpatient Department User Satisfaction Rapid Scale.

design and evaluation, confers face value and criterion validity to ERSaPaCE. This way, the scale allows an evaluation of different aspects of outpatient care, including those inherent to the medical unit, as well as those involving the medical-paramedical and administrative staff (medical records department), similar

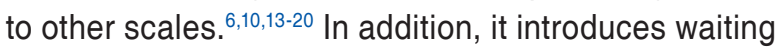
time (an important indicator of the quality of the service) and the opportunity for the patient to express any positive or negative opinion (congratulations, suggestions or complaints), bringing the patient closer to the service provider. The latter two innovative aspects make for the scale to provide highly useful information for health services administrators.

Full completion of the questionnaire is favored by its short extension: it consists only of 10 items that are rapidly and easily answered and a written opinion (optional), which is a great advantage in relation to other more extensive, more elaborate scales or instruments to be answered before and after the visit (appointments). All our patients completed the survey, and thus no one was eliminated. In addition, the faces designed by García Galicia et al., which have demonstrated great consistency and construct validity for subjective global scales, ${ }^{12}$ were added as an equivalent to the values for each item.

The participation of different quality assessment experts who serve both in operational and directive areas, and who kept within the purposes of rapidness and practicality, gave the questionnaire a high value in terms of soundness and face value (construct validity).

When assessing patient satisfaction, the surveyed population was distributed in a gender-balanced manner, which avoided the bias that might exist for this reason. Regarding the age of the respondents, a wide 
range of ages was obtained that included young, mature and older adults.

The specialties and departments involved were diverse (13 different specialties) and, sometimes, more than one doctor of some specialty was involved, which demonstrates the applicability of the scales.

ERSaPaCE registered an internal consistency of 0.608 by Cronbach's $\alpha$, perhaps because it consists of few items (only 10) and because the aspects of the outpatient care process that were assessed were also quite varied and, presumably, of an independent behavior (assistants, nursing staff, doctors, medical records department, pharmacy, etc.). However, it showed acceptable convergent validity with SUCE, which in its validation recorded 0.8 by the same test. ${ }^{10}$

Given the characteristics and temporality of our study, exploration of the sensitivity to change remains outstanding, perhaps with the comparison of patient satisfaction before and after some maneuver intended to modify the outpatient care process, and thus improve the quality of care in this modality.

The findings of this work allow us claiming that ER$\mathrm{SaPaCE}$ is valid and consistent and that it constitutes a useful alternative to assess the quality of care in medical units.

\section{Funding}

The authors received no aid or funding for the present work.

\section{References}

1. Empaire G. Calidad de atención médica y principios éticos. Acta Bioethica. 2010;16:127-132.
2. Fernández-Busso N. Calidad de la atención médica. Programa de Educación a Distancia [en línea]. Argentina: Sociedad Argentina de Calidad en Atención de la Salud; 2019.

3. Aguirre H. Administración de la calidad de la atención médica. Rev Med IMSS. 1997:35:257-264.

4. Aguirre-Gas HG. Sistema ISO 9000 o evaluación de la calidad de la atención médica. Cir Cir. 2008;76:187-196.

5. Aguirre H. Evaluación de la calidad de la atención medica expectativas de los pacientes y de los trabajadores de las unidades médicas. Salud Publica Mex. 1990;32:170-180.

6. Vera J, Trujillo A. El efecto de la calidad de vida del servicio en la satisfacción del derechohabiente en instituciones públicas de salud en México. Contaduría y Administración 2018;63:1-22.

7. Consejo de Salubridad General. Estándares para la Certificación de Hospitales 2012 [en línea]. México: Consejo de Salubridad General; 2013.

8. González-Medécigo LE, Gallardo-Díaz EG. Calidad de la atención médica la diferencia entre la vida o la muerte. Rev Digit Universitaria. 2012:13:1067-1071

9. Crossing the quality chasm: a new health system for the $21^{\text {st }}$ Century Committee. EE. UU.: Institute of Medicine/Committee on Quality of Health Care in America; 2001.

10. Cabello E, Chirinos JL. Validación y aplicabilidad de encuestas SERVQUAL modificadas para medir la satisfacción de usuarios externos en servicios de salud. Rev Med Hered. 2012;23:88-95.

11. Empaire G. Calidad de atención médica y principios éticos. Acta Bioethica. 2010;16:127-132.

12. Ramírez TJ, Nájera P, Nigenda G. Percepción de la calidad de la atención de los servicios de salud en México: perspectiva de los usuarios. Salud Publica Mex. 1998;40:1-10

13. Aguirre-Gas HG, Zavala-Villavicencio JA, Hernández-Torres F, Fajardo-Dolci G. Calidad de la atención médica y seguridad del paciente quirúrgico. Error médico, mala práctica y responsabilidad profesional. Cir Cir 2010;78:456-462.

14. Granado S, Rodríguez C, Olmedo MC, Chacón A, Vigil D, Rodríguez P. Diseño y validación de un cuestionario para evaluar la satisfacción de los pacientes atendidos en las consultas externas de un hospital de Madrid en 2006. Rev Esp Salud Publica. 2007;81:637-645.

15. García-Galicia A, Lara-Muñoz MC, Arechiga-Santamaría A, Montiel-Jarquín AJ, López-Colombo A. Validez y consistencia de una nueva escala (facial del dolor) y de la versión en español de la escala de CHEOPS para evaluar el dolor posoperatorio en niños. Cir Cir. 2012;80:510-515.

16. García-Galicia A, García-Carrasco M, Montiel-Jarquín AJ, García-Cuautitla MA, Barragán-Hervella RG, Romero-Figueroa MS. Validez y consistencia de las escalas ECAVIPEP y CAVE para evaluar la calidad de vida en pacientes pediátricos con epilepsia. Rev Neurol. 2014;59:301-306.

17. Gerónimo-Carrillo R, Guzmán-Cejas L, Magaña-Olán L, Ramos-Rendón KC, Calidad del servicio en la consulta externa de un centro de salud urbano de Tabasco. Rev Salud Quintana Roo. 2016;9:11-15.

18. Feldman L, Vivas E, Lugli Z, Pérez MG, Bustamante S. La satisfacción del paciente hospitalario: una propuesta de evaluación. Rev Calidad Asistencial. 2007;22:133-140.

19. López-Toledano MC, Luque-Cantarero I, Gómez-López VE, Casas-Cuesta R, Crespo-Montero R. La satisfacción del paciente como componente de la calidad en las unidades de diálisis. Enfer Nefrol. 2016;19:125-133.

20. Simancas-Pallares M, Arévalo-Tovar L. Desempeño de cuatro métodos estadísticos para evaluación de la concordancia prueba-reprueba de variables continuas en una muestra. Rev Biosalud. 2017;16:19-29. 